\title{
REVIEW ON CLIMATE RESILIENT PRACTICES FOR SMART FARM WOMEN
}

\section{R.HARIHARAN* \&Dr. J.JANE SUJATHA}

Department of Extension Education and Communication Management, Community Science College and Res. Institute, TNAU, Madurai, India

\begin{abstract}
During the year 2011-2012, the Gross Domestic Product (GDP) of the nation has reached about fourteen percent by the contribution from agriculture and allied sector. Farm women labourers face persistent obstacles and economic constraints despite being the major source of work force in agriculture. To create stability in the farmers' income and to sustain the crop production, there is an immediate need to efficiently use the natural resources to enable farmers. Adaptation to the changing climate and readiness to evolve in new technologies would help the farmers attain crop yields to the maximum. Enhancing climate resilient practices, developing livestock protecting technologies and energy efficient house hold practices would guide to address the concerns of climate change and lead the farming community towards sustainable development goals. The paper thus presents the various climate resilient practices suitable for enhancing the farming knowledge towards demonstrating the best practices that guide farm women with the current climate variability.

KEY WORDS: Farm women, Agriculture, Climate change, Sustainability\& livelihood
\end{abstract}

Received: Aug 08, 2020; Accepted: Aug 28, 2020; Published: Sep 26, 2020; Paper Id.: IJESRAUG202012

\section{INTRODUCTION}

Among the various developing nations, India belongs to a nation containing farmers below poverty line. Our nation is prone to varied weather shocks and increased level of food insecurity mainly observed in rural and small land holding farmers. Fifty eight percent of the people are agriculture workers in India ${ }^{1}$. Coping with climate variability and imperative livelihood security of small and marginal farmers would become reliable only with enhancing the resilience of Indian agriculture. Indigenously, transfer of technology in agriculture leads to increased productivity in farming. Still, there is a need to support farmers during droughts, floods and other extreme climatic events to adapt innovative technologies and practices for their better livelihood.

The various climate resilient practices that enhance the productivity and income of farm women are given under various practices on agriculture, livestock and household levels.

\section{AGRICULTURE}

\section{Establishing A Staggered Community Paddy Nursery During Deficit Rainfall Season}

During the deficit rainfall season there is a need to develop paddy nursery, in which the technique involves raising of staggered nursery with assured irrigation facility in selective villages at an interval of fifteen days. In order to cope up with the problem experienced by farmers during deficit rain fall season, establishment of staggered community nursery would be recommended as the strategy in villages ${ }^{2}$. 
Drought tolerant and short duration variety of paddy to manage rainfall situations and technique for expected monsoon delay and water shortage problem

Transplanting of paddy:

- $\quad$ Twenty-five ha-cm of water for puddling operation.

- $\quad$ Creates a dense clay layer in the sub-soil to prevent seepage losses.

- $\quad$ Produce about $10 \%$ of global methane emission.

- Injudicious use of nitrogenous fertilizers, which is a source of nitrous oxide emission ${ }^{3}$.

Excessive exploitation of ground water has occurred due to the current injudicious practices thereby by lead to decline in the quality of land and water for use. Direct Seeded Rice (DSR) means sowing of rice seeds directly in the soil. While change in monsoon and shortage of water, DSR helps the farm women to take up sowing directly during suitable duration variety to fit in the season. The demand for irrigation is also less than DSR when comparing with the transplanting $\operatorname{method}^{4}$.

When Short duration paddy varieties are sown in DSR method can provide a significant yield in areas experiencing increased frequency of droughts.

\section{DESILTING AND DEEPENING OF COMMUNITY TANKS / PONDS WITH FARMERS' PARTICIPATION AND WATER SAVING IRRIGATION METHODS}

Water source is very much necessary for irrigating the land and for farming activities. Storage of water would help during water scarcity periods and thereby support for better soil health and during flood conditions. A large number of tanks with substantial water storage capacity, constructed long ago,have become defunct due to neglect, non-maintenance and silting $u^{6}$.Cleaning up of irrigation channels for farming and developing effective technologies for avoiding desilting in the irrigation channels help and support the farming community to receive water for irrigation regularly. As an aspect of better water saving irrigation methods, the cleaning up of the irrigation channels in the field was carried out in the village.

\section{LOW COST RAINWATER HARVESTING STRUCTURE}

Rainwater is a natural resource that entangles for irrigation cannels and farm lands in storing water. The technique that requires minimal resources and would guide through better water storage capacity is the rain water harvesting methods. During dry season, adequate amount of water can be stored using rain water harvesting technique. In moisture scarcity condition also farming can be done properly with adequate amount of water for irrigation through adoption of rain water harvesting system ${ }^{7}$. The wells and the ponds in the farming land,which are connected with inlets from irrigation channels to store water during rainy season and to avoid water runoff in the fields, can be cleaned and maintained.

\section{PARTICIPATORY VILLAGE LEVEL SEED PRODUCTION AND STORAGE OF SEEDS THROUGH SEED BANKS}

Natural resources can be developed and processed for security in farming. But the seed shortage of suitable crops varieties for the land area in the particular locality and the soil condition necessary for some specific crop variety is particular to be available for crop production. In areas, where the farmers have good natural resources but, still they lack in production of 
local seed varieties suitable for their land to increase the productivity. This condition lead to low profit to the framer and it also reduces the fertility level of the soil ${ }^{8}$. Thus, to avoid the losses attained through such conditions, suitable varieties of main and sub crops of the area has to be produced and stored in the villages itself as seed banks. This would directly support the farmers in the locality to produce high productive crop and help farmers during drought conditions.

\section{SMALL FARM MECHANIZATION THROUGH RESOURCE CENTRES FOR FARM TOOLS}

Mechanization of the farming operations would support the farmers to complete the tasks at timely schedules and met the requirement of farm women. Development of tools which are low cost and help in reducing the drudgery of farming operations of women support the land holders to increase the productivity.

\section{ADVANTAGES}

- $\quad$ Efficient use and less time consuming.

- Availability of appropriate tools necessary for local farming crops at hiring is better for usage.

- $\quad$ Cropping intensity can be increased.

- $\quad$ Prevention of burning of residues.

- The cultivation cost and labour cost can be reduced.

\section{LIVESTOCK}

\section{INTRODUCTION OF IMPROVED BACKYARD POULTRY INTERVENTIONS (BREEDS) VANARAJA CHICKS AND IMPROVED SHELTER FOR CHICKS}

Livestock rearing is one of the best alternatives for today's climate changes and drought conditions. Practicing local variety livestock poultry and development of backyard poultry would support for synthesis of regional variety poultry and it reduces the burden on rearing. Vanaraja chicks can be practiced with brooding during the primary stage of living of the chicks and grain with supplementation for better growth of the backyard poultry. This is a potential practice that allows to generate income at household level itself.

\section{Provision of Proper Roof and Shelter to Manage Climatic Conditions for Livestock}

The change in climate and the everyday modifying scenario of the weather is currently alarming for the living beings in the universe. The environment with more heat and very cold conditions would rather lead to be the major challenge for lives of the animals in the shelters. Provision of proper shelter for the animals would support and guide the animals to be safe and reduce the stress on heat for the animals. Development of effective shade and shelter for livestock would reduce the possibility of death of the animals and would help to produce large amount of livestock in a healthier manner. A slatted floor with proper roofing is a semi intensive system for rearing goats ${ }^{10}$. Some farmers prefer to provide the shelter for the livestock in more shady areas and this would help the animals to live safely. Mostly tree shade is provided or the movement of animals during night is restricted by fencing the area with bamboo /wooden/iron material ${ }^{11}$. Locally available materials can be used for providing shelter for the animals. One inch gap can be provided between each slat to collect urine and faecal matters of the animals from the bottom of the floor ${ }^{12}$. Thus, by providing proper shelter for animals, their life expectancy would increase and it would also support the farm women to generate more income from livestock. 


\section{PREVENTIVE VACCINATION FOR LIVESTOCK}

Vaccines are one of the most cost-effective and sometimes the only means to prevent disease in livestock populations, including zoonotic diseases ${ }^{13,14}$. The quality and quantity of livestock production in any area can be secured through proper vaccination and care given to the livestock. The schedule of vaccination can be shared with the farming community and the livestock practices can be demonstrated including feeds for the livestock can be distributed to the farm women for rearing. Many commercial available vaccines are promoted to cure the diseases and secure the growth of livestock, but still the reach of the vaccines to the rural women should be ensured through proper management practices.

\section{HOUSEHOLD}

\section{Installing Solar Energy Lamps}

Solar energy is a non-renewable energy resource, which is most effective to be utilized and maintained in household level. In the changing world of cost effective and self-regulated structures, it is necessary that the solar energy be utilized in houses for non-stoppable maintenance and better usage for the people ${ }^{15}$. Solar energy can be utilized for easy method of transferring electric energy and to enable women to have free electricity charges. Even the solar lamps can be utilized even in places of non-availability of electricity. Solar lamps, solar batteries and solar pumps can be promoted to the household and maintain the better living of the women in rural areas.

\section{Rainwater Harvesting at Houses}

A rainwater harvesting system comprises components of various stages - transporting rainwater through pipes or drains, filtration, and storage in tanks for reuse or recharge ${ }^{16}$. This rain water harvesting method can be adopted in backyards of households where the water can be stored and regularly purified through transport of rain water to the soil and recharge the land water capacity. This directly interacts to providing water resource for household usages.

\section{CONCLUSIONS}

Adaptation to new innovative technique is essential for sustainability of farming. This adaptation can be acquired by increasing the production, by adopting varieties of technologies, adopting sustainable land management practices. Though agriculture technologies are available worldwide, still the scope of adaptation of the technologies in the various regions is not possible due to the diverse varieties of lands, soil, water and climate conditions. Delivering of the technologies suitable for the local area and transfer of appropriate technique to local species production would support the farming for further development. Women being involved in agriculture; it is their involvement in the climate change issues that would evolve towards sustainable agriculture.

\section{REFERENCES}

1. Prasad, YG., Maheswari, M., Dixit, S., Srinivasarao, Ch., Sikka, AK., Venkateswarlu, B., Sudhakar, N., Prabhu Kumar, S., Singh, AK., Gogoi, AK., Singh, AK., Singh, YVand Mishra, A. (2014). Smart Practices and Technologies for Climate Resilient Agriculture. Central Research Institute for Dryland Agriculture (ICAR), Hyderabad. 76 p.

2. Betzold, C., \& Weiler, F. (2017). Allocation of aid for adaptation to climate change: Do vulnerable countries receive more support? : Politics, Law and Economics, 17, 17-36. 
3. Bhattacharyya, R., Das, T., Sudhishri, S., Dudwal, B., Sharma, A., Bhatia, A., et al. (2015). Conservation agriculture effects on soil organic carbon accumulation and crop productivity under a rice-wheat cropping system in the western Indo-Gangetic Plains. European Journal of Agronomy, 70, 11-21.

4. SAIKIA, BORNALI, and AJANTA BORGOHAIN RAJKONWAR. "A STUDY ON THE PROBLEMS FACED BY RURAL WOMEN SHGS IN DIBRUGARH DISTRICT, ASSAM." International Journal of Economics, Commerce and Research (IJECR) 9. 2, Dec 2019, 29-38 @ TJPRC Pvt. Ltd.

5. Chen, Z., Wang, H., Liu, X., Zhao, X., Lu, D., Zhou, J., et al. (2017). Changes in soil microbial community and organic carbon fractions under short-term straw return in a rice-wheat cropping system. Soil and Tillage Research,165, 121-127.

6. Matsuda, A., \& Kurosaki, T. (2019). Demand for temperature and rainfall index insurance in India. Agricultural Economics, 50(3), 353-366.

7. Bhandari, G. (2013). Effect of rainfall on the International Environmental Agreements yield of major cereals in Darchula district of Nepal. International Journal of Environment,3, 205-213.

8. Sharma, Aneesya, and A. V. N. I. S. H. Sharma. "Women entrepreneurs: A surge to break the image of housewives." International Journal of Economics, Commerce and Research (IJECR) 3.3 (2013): 61-68.

9. Deutsch, C. A., Tewksbury, J. J., Tigchelaar, M., Battisti, D. S., Merrill, S. C., Huey, R. B., et al. (2018). Increase in crop losses to insect pests in a warming climate. Science,361, 916.

10. Fishman, R. (2018). Groundwater depletion limits the scope for adaptation to increased rainfall variability in India. Climatic Change, 147, 195-209.

11. Banu, Nasreen, and A. Mrunalini. "Empowering young farmers in the context of climate change." (2017). International Journal of Agricultural Science and Research (IJASR) 7. 2, Apr 2017, 449-456

12. Gathala, M. K., Kumar, V., Sharma, P. C., Saharawat, Y. S., Jat, H. S., Singh, M., et al. (2013). Optimizing intensive cerealbased cropping systems addressing current and future drivers of agricultural change in the northwestern Indo-Gangetic Plains of India. Agriculture, Ecosystems and Environment,177, 85-97.

13. Dhanapal, G. (2014). Climate adaptation in India. Nature Climate Change,4, 232.

14. GoI. (2008). India: National action plan on climate change (NAPCC). New Delhi: Government of India.

15. Choi, Seungho, et al. "Success Factors for Luxury e-commerce: Burberry's Digital Innovation Process." International Journal of Information Systems Management Research and Development (2014): 1-10.

16. Habiba, U., \& Shaw, R. (2014). Farmers' response to drought in Northwestern Bangladesh. Risks and conflicts: Local responses to natural disasters (pp. 131-161). Bradford: Emerald Group Publishing Limited.

17. Shankar, K. R., Nagasree, K., Nirmala, G., Prasad, M., Venkateswarlu, B., \& Rao, C. S. (2015). Climate change and agricultural adaptation in South Asia. In L. Filho (Ed.), Handbook of climate change adaptation (pp. 1657-1671). Berlin: Springer.

18. Jalota, S., Kaur, H., Kaur, S., \& Vashisht, B. (2013). Impact of climate change scenarios on yield, water and nitrogen-balance and-use efficiency of rice-wheat cropping system. Agricultural Water Management,116, 29-38.

19. Kalra, N., Chander, S., Pathak, H., Aggarwal, P., Gupta, N., Sehgal, M., et al. (2007). Impacts of climate change on agriculture. Outlook on Agriculture,36, 109-118. 
20. Kumar, M. D. (2016). Water saving and yield enhancing micro irrigation technologies in India: Theory and practice. In Micro irrigation systems in India (pp. 13-36). Berlin: Springer. 